\title{
The spiritual weakness of churches founded by Western missionaries: The cause of the rise of Africa Independent Churches in Zimbabwe with special reference to the Uniting Presbyterian Church in Southern Africa
}

\begin{tabular}{|c|c|}
\hline \multicolumn{2}{|c|}{$\begin{array}{l}\text { Authors: } \\
\text { David Mushayavanhu } \\
\text { Graham A. Duncan }{ }^{1}\end{array}$} \\
\hline \multicolumn{2}{|c|}{$\begin{array}{l}\text { Affiliations: } \\
{ }^{1} \text { Department of Church } \\
\text { History and Church Polity, } \\
\text { University of Pretoria, } \\
\text { South Africa }\end{array}$} \\
\hline \multicolumn{2}{|c|}{$\begin{array}{l}\text { Correspondence to: } \\
\text { Graham Duncan }\end{array}$} \\
\hline \multicolumn{2}{|c|}{$\begin{array}{l}\text { Email: } \\
\text { graham.duncan@up.ac.za }\end{array}$} \\
\hline \multicolumn{2}{|c|}{$\begin{array}{l}\text { Postal address: } \\
\text { Faculty of Theology, } \\
\text { University of Pretoria, } \\
\text { Pretoria } 0002 \text {, South Africa }\end{array}$} \\
\hline \multicolumn{2}{|c|}{$\begin{array}{l}\text { Dates: } \\
\text { Received: } 06 \text { Sept. } 2013 \\
\text { Accepted: } 29 \text { July } 2014 \\
\text { Published: } 28 \text { Nov. } 2014\end{array}$} \\
\hline \multicolumn{2}{|c|}{$\begin{array}{l}\text { How to cite this article: } \\
\text { Mushayavanhu, D. \& } \\
\text { Duncan, G.A., 2014, } \\
\text { 'The spiritual weakness } \\
\text { of churches founded by } \\
\text { Western missionaries: The } \\
\text { cause of the rise of Africa } \\
\text { Independent Churches in } \\
\text { Zimbabwe with special } \\
\text { reference to the Uniting } \\
\text { Presbyterian Church in } \\
\text { Southern Africa', Verbum et } \\
\text { Ecclesia } 35(1), \text { Art. \#1254, } \\
6 \text { pages. http://dx.doi. } \\
\text { org/10.4102/ve.v35i1.1254 }\end{array}$} \\
\hline \multicolumn{2}{|c|}{$\begin{array}{l}\text { Copyright: } \\
\text { C 2014. The Authors. } \\
\text { Licensee: AOSIS } \\
\text { OpenJournals. This work is } \\
\text { licensed under the Creative } \\
\text { Commons Attribution } \\
\text { License. }\end{array}$} \\
\hline \multicolumn{2}{|l|}{ Read online: } \\
\hline 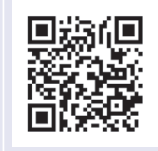 & $\begin{array}{l}\text { Scan this QR } \\
\text { code with your } \\
\text { smart phone o } \\
\text { mobile device } \\
\text { to read online. }\end{array}$ \\
\hline
\end{tabular}

The Presbytery of Zimbabwe (POZ) of the Uniting Presbyterian Church in Southern Africa (UPCSA) has been affected by a drastic exodus of members to African Independent Churches, which is taking advantage of its spiritual weaknesses in its missional endeavour. The spiritual weaknesses which the people of the POZ experiences are a product of the evangelical mode of mission in Zimbabwean society and the failure by both foreign and local personnel to contextualise the Good News. This article considers the possibility of correcting this state of affairs. The central issue addressed is how to understand the context and achieve the necessary change.

\section{Introduction}

Churches founded by Western missionaries have mostly failed to regard African religious beliefs as a foundation for faith in Christ (cf. Bediako 1999). African beliefs are not 'dead works' but an inauguration, a foundation, an inspiration and a stimulation for the Christian faith. African religious life is not just a scaffold, but it contains ingredients that qualify it to be a model religion for the Christian (Bediako 1999:225-266; Nyirongo 1997:1). Africans are religious in all aspects of life, and a failure in any one sphere of life requires a religious solution. In this area, African Initiated Churches (AICs) fill the vacuum left by churches founded by Western missionaries or the Uniting Presbyterian Church in Southern Africa (UPCSA). The latter have not been able to fill the vacuum caused by missionaries because they brought an enlightenment-based faith which differentiates faith from the rest of life. This failure results in the African members of the Presbytery of Zimbabwe (POZ) continually and secretly seeking help from independent churches to fulfil their quest and need for a holistically based faith.

The rejection of the imposition of a 'foreign body' in the form of Western Christianity and the strive '... towards recognition of their common pursuit in this existence of the quest for belonging ...' (Daneel 1987:17) gave birth to AICs. They became popular through their contextualisation of the gospel and through the identification of and with the needs of their members in a more pragmatic and practical sense. Thus, they provide a positive and muchneeded approach to the community. Through this approach, they are winning many souls, especially disgruntled members from churches founded by Western missionaries in the POZ. The AICs provide '... a place to feel at home' (Daneel 1987:18). The gospel was promoted in Zimbabwe in the guise of Western culture with the intention of replacing African culture (Turaki 1999:7-19). Zimbabwean society knew Mwari (god) before the advent of the churches founded by Western missionaries whose God is above all things (Mahoso, pers. comm., 04 August 2012).

Desmond Tutu (1978:366) spoke of redeeming the 'hidden treasures' (the riches of African culture, that which is yet to be tapped into and put to good use in cultivating African Christianity). For example, rukwa is a practice that secures one's property and acts as magnet to trap a thief and prevents the thief from getting away with stolen item(s). Barika [polygamy], amongst many others, is integral to African religion, making it a scaffold for the new Christian faith. Issues like ngozi [avenging spirit] and huroyi [witchcraft] caused a great many people to leave the church because they are most feared by African worshippers in Zimbabwe. It is reassuring to know that Africans have had a genuine knowledge of God and that they have had their own ways of achieving communion with the deity, ways which meant that they were able to speak authentically and not as pale imitators of others. It means that they can fashion new ways of speaking to and 
about God and develop new styles of worshipping reliably with invigorated faith. Addressing Africanness is where the African Independent Churches fill the gap left by churches founded by Western missionaries.

\section{The UPCSA comes to Zimbabwe}

The churches founded by Western missionaries or UPCSA operate on a number of assumptions. For instance, the Zimbabwean society was seen as having been left behind in the process of development. It needed civilisation and religion for it to catch up with the outside world. Missionaries rightly noticed that the Zimbabwean society needed purification from evil practices (in the eyes of the Western world) such as the killing of the twins and polygamy. Their approach, however, fell short of the purification process because, instead, they aimed at destroying traditional society, thereby creating a totally different one (Bourdillon 1973:11; Magava 1986:5-12). The local people failed to feel that Christianity was their religion as it was taken as part and parcel of the forces which tore apart their society and religion. Hence, when AICs created a different atmosphere, they won the natives' loyalty.

The Zimbabwean community was also found to be worshipping in a communal way; people were drumming, singing, dancing, clapping and whistling. The locals viewed ancestors as the mediators between themselves and God. The change of politics and economics introduced by the missionaries had negative effects on the community beliefs (Mahoso, pers. comm., 04 August 2012). In the African world before the advent of Western missionaries, politics and economics were tied together in religious phenomena whereby the political leader was also the religious custodian and in control of national or regional commerce. The dawn of Western philosophy eroded such powers and hence challenged the African beliefs.

The UPCSA came from Europe to evangelise and operated as though in Europe there had been no need to contextualise the gospel in order for it to be relevant. It emphasised conversion, leaving Africanness (Weller 1984:10), thereby transmitting the Christian message through dissemination and transformation (Mukonyora 1993:147). Conversion meant changing their converts into being like the missionaries in all respects, including values, norms and ethos.

Missionaries promoted civilisation and commerce. They erred by refusing to understand Africans and characterised their religion as either non-existent or devilish (Bourdillon 1973:28). The inconsistency in missionary thought is clear when they call a non-existent phenomenon real. Missionaries did not pay heed to the complex and highly organised systems of Zimbabwean religions. Missionary education systems came packaged and were based on pouring information or knowledge from superior minds into the empty pupil (Banana 1991:30).

Evangelism was a pastoral task for a future generation, centred on quantity of converts at the expense of quality
(Baur 1994:107). In the process of evangelism, the missionaries colonised the nation. This meant that the natives lost their trust and confidence in the missionaries (Zvobgo 1996:1). The dawn of AICs in the late 19th century came as a relief for the aggrieved community who voted with their feet by moving away from churches founded by Western missionaries. The latter promoted health, education commerce and agriculture but failed to study the psychology of the people of Zimbabwe. Hence, they were not ready to compromise either their beliefs or their approach to mission (Weller 1984:204).

The UPCSA came to Zimbabwe through the South African corridor as early as 1896 when the first 'independent' congregation was established in Bulawayo, followed by Salisbury (Harare) in 1903. By this time, the Presbyterian Church had been formed in 1897 with its first General Assembly in Durban (Bax 1997:10). Other congregations were established along with eight Presbyterian schools, including Gloag Ranch (Bax 1997:10). Many great changes occurred, including the building of the first structure in Makokoba, Bulawayo in 1896, dedicated in 1916 (Nkumalo, pers. comm., 02 July 2012). The POZ grew predominantly in urban centres. The Presbyteries of Mashonaland and Matabeleland were constituted. They were united in 1993 along with the congregation at Livingstone to form the Presbytery of Zimbabwe (Bax 1997:10). These were predominantly white congregations. Bax (1997) comments that:

... the Church and Nation Committee (Rhodesia), in spite of being urged to do so, failed ever to propose to the [General] Assembly any emphatic indictment of the policies of the Government of Ian smith or any kind of support for the liberation struggle there. (p. 37)

This demonstrates the politically conservative nature of Presbyterianism in Zimbabwe. In 1959, white Presbyterians in Zambia refused to be part of the non-racial negotiations for union in Zambia (Bax 1997:16). The situation changed rapidly following independence in 1980. Some white congregations began to integrate, and the number of black candidates for the ministry increased. The POZ is now one of 19 Presbyteries in the denomination throughout Zambia, South Africa and Zimbabwe. In 2006, the POZ introduced a growth mechanism in the form of regions, drawn geographically for easy administration and co-ordination (POZ 2006). Its reports to the General Assembly are detailed in their comments on social responsibility issues (UPCSA 2008:240, 278, 2009:140, 2010:193-195) but are silent on matters of losses in membership.

The POZ leadership, both Western and local, failed to contextualise the gospel or accommodate the African people (Zwana, pers. comm., 29 October 2010). They came condemning the core values of the African people, including the African reverence towards the departed fathers which was viewed as worshipping the dead, the paying of lobola as selling and buying of women and the denial of using the locally available elements for Communion services such as sadza and mahewu. 
With sound Confessions of Faith, Articles of Faith and a Manual of Faith and Order, pencilled by the white man's hand as guiding principles governing the UPCSA, people are still leaving for AICs without the guidance or even without shelter and sanitation because these Western instruments alone do not speak to the hearts of people. A random statistical survey made by this writer reveals that at least 350 people leave the UPCSA every three months in congregations in Harare (congregations assessed were Trinity, Kuwadzana, Mbare, Chitungwiza Highfields: Dzivarasekwa, Highlands, City, Mabouku Hatfield and St Stephens, including their peri-urban out-stations) for either the AIC or Pentecostal churches. Those in leadership positions include elders, youth, women and evangelists. The two evangelists who left the POZ (names kept for security reasons) formed their own gatherings in the suburbs of the capital city.

\section{Missional weaknesses of the UPCSA and POZ}

The UPCSA has survived many challenges and obstacles. They have done a great deal for African Christians in many spheres of life such as education. However, there is still much more to be done by the UPCSA in order to truly satisfy the quest for African spirituality and withstand the challenges befalling it. In some aspects, little if anything has been done to make Christianity more relevant to the African context. One would expect that, with such a long history, the UPCSA should have become more contextually grounded by now, but alas, they have failed.

An issue arose in the 2002 General Assembly which reflected the low regard in which the members of the denomination in Zimbabwe and Zambia were held - this again in a committee whose membership was dominated by white persons, the Finance Committee. The offending comment was: 'Unhappiness [within the denomination] at continued drain on resources for ongoing support of Zambia and Zimbabwe' (UPCSA 2002:393). For the Zambian and Zimbabwean commissioners, this was the last straw in an ongoing struggle for recognition as equal partners in the church. It led again to the question of their remaining within the UPCSA. In addition, the offending statement failed to take any account of the extremely poor and deteriorating economic and political situation in both countries. This was a crisis for the UPCSA. After intense discussions, the Moderator of the General Assembly, Rt Rev M.K. Boshomane addressed the Assembly (UPCSA 2002):

I wish, in face of this court, to declare to our brothers and sisters from Zambia and Zimbabwe that the comments and perceptions of the Finance Committee ... are not the official position, policy or opinion of this Assembly.

On behalf of the Assembly I wish to apologise for the hurt caused by this humiliating and embarrassing assault on the dignity of the commissioners from these two countries present at the Assembly and other members of the UPCSA in the two countries. (p. 473)

However, the hurt remained.
Issues relating to Christ and culture were recurrent in the UPCSA, recently established in 1999. In 2003, the white dominated Doctrine, Ethics and Discipline Committee brought the following proposals, which were adopted by the General Assembly (UPCSA 2003):

2) The Assembly adopts the following tenets as a basis for debate within the church on matters relating to different forms of cultural practice:

(a) Christ comes to us and we come to Him within the medium of culture;

(b) All cultures are compromised by sin and redeemed through Christ;

(c) It is through Christ alone that God comes to us and we come to Him;

(d) The Lordship of Jesus Christ is the final determining factor for the evaluation of every culture. (p. 516)

This same General Assembly set up a consistory on Christ and culture as a sub-committee of the Doctrine, Ethics and Discipline Committee. It never functioned and was dissolved two years later. This was due to the failure of black participation which was occasioned by frustration in discussions. One of the authors of this article (Duncan) had the recurrent experience in the UPCSA of white ministers approaching black ministers with the request: 'Please tell me about ancestor veneration so I can just understand it.' What followed was an interrogation (not listening) which betrayed the intention of understanding the practice but rather demonstrated the discussion as a springboard for negative critique. When it came to specific matters such as the peripheral (to some) matter of the elements used in the sacrament of Holy Communion, the General Assembly (UPCSA 2008:443) was adamant. The context was a request for the Presbytery of Thekwini (Durban and environs): 'The Assembly therefore rules that only wine or grape juice may be used as the element that signifies the blood of Christ in the Sacrament of the Lord's Supper' (UPCSA 2008:443). This decision was based on the UPCSA Confession of Faith and the Westminster Confession of Faith (1643) and was '... cognisant of the fact that the Africanisation of Christian worship, [w] as a part of finding an authentic African cultural embodiment and expression of Christianity' (UPCSA 2008:291).

This decision took no account of the cultural context in any of its constituent countries. It was explained when the matter was sent to the Doctrine, Ethics and Discipline Committee (UPCSA 2008):

Some ministers within the Presbytery, with the intention of celebrating and affirming African culture in a Christian expression and within the church, in the context of successive Heritage Days, took to two congregations the exhortation to choose Zulu beer in place of the wine at the Lord's table (the wine still being available as an option). (pp. 290-291)

This discussion has to be viewed in the light of the UPCSA Faith of the Church (UPCSA 2007):

In Scripture revelation comes to us clothed in the culture of the ancient Middle East. To communicate the good news to others 
we need to express it in their language and cultural concepts. As the good news takes root, it becomes embodied in a particular culture. (§12.1:2.15)

Thereafter follows a warning about the relativity of culture, especially with regard to ancestor veneration which is a particular problem for white church members. This admonition seems to pay lip service to the admission that Christianity came in a particular culture while still retaining the power to impose restrictions on its expression. Balcomb (2014:56) expresses it this way:

The African world view that they describe as being adhered to by 'hundreds of millions' of people is consistently referred to in terms of the occult and superstition by western scholars which betrays their own bias to the subject in hand and cannot advance the cause of better understanding. (p. 56)

Hence, the POZ and its denominational missional weaknesses caused a spiritual thirst that forced people to roam around for gratification thereby leading to many new church movements.

'The churches founded by Western missionaries provide a holistic approach to the whole person', is a statement with which the UPCSA associates. The question is: Is this statement true? A critical analysis reveals that such churches are to a large extent lacking in the provision of a holistic approach. Hence, the UPCSA's weaknesses and its repercussions in the present-day context need to be explored. The weaknesses include a failure to dialogue with important African cultural aspects such as rites of passage, African instruments and worshipping style, prophetic ministry, liturgy, failure to penetrate tribal grounds and the ratio of clergy to laity.

In the POZ, council meetings are abused, used as platforms to fight or settle scores. Members even use abusive language in council meetings. This has since given birth to a 'new Presbytery of South West - Bulawayo region', purported to be developing the current Presbytery into two. However, Ndebele-speaking people feel threatened and hence withdrew along tribal lines (UPCSA 2012). There is a lack of 'koinonia', fellowship (Henderson 1967:10-13). Spiritually weak elders translate to weak Sessions and this cascades to General Assembly level. This is due to a lack of proper training of members in the office of elder. Almost all worship services take place on Sundays. There is no midweek worship meetings save for the women's fellowship.

\section{What UPCSA and POZ can learn from African Initiated Churches?}

The pattern established by missions in Zimbabwe over one hundred years has created two massive problems. First, control still lies with parent churches and organisations centred in South Africa, especially as far as theological education and funding are concerned. Apart from reporting to the General Assembly on matters of justice and social responsibility (i.e. political) (UPCSA 2012:225-228), the POZ has no substantial input into the General Assembly. Secondly, local churches have internalised the dependency pattern to such an extent that they are blind to their potential for taking their own initiatives. This is one reason why they are accused of becoming a 'drain' on financial support from South Africa. The POZ and UPCSA, like the AICs, must start learning to 'drink from their own wells'. However, as long as the POZ is still trapped in the paternalistic structures of the mission societies which gave them birth, this dream seems very distant.

The writers could be misinterpreted as though we are implying that the UPCSA should surrender her Presbyterian heritage and become an AIC. The UPCSA is rooted in Calvinism, and this position need not change, but by learning from the AICs in certain areas, this Presbytery could grow to its full potential. Finally, the writers are aware that the AICs have their fair share of faults and shortcomings. Irrespective of such inadequacies, the AICs have really lived up to the challenges of the time, and the UPCSA can tap into so many resources from these churches.

A number of contributions which have been hinted at above could benefit the POZ and its partners in a quest for possible approaches and opportunities for future partnership. This study attempted to look at the weaknesses of the UPCSA and POZ as a phenomenon in its own time. The AICs have taken the lead in an endeavour to live up to the selfprinciple, that is, self-governing (cf. Daneel 1987:138-213), self-supporting (cf. Daneel 1987:178-179), self-propagating (cf. Daneel 1987:25-28) and self-theologising (cf. Daneel 1987:245-280). In this way, they are growing spiritually as well as numerically. The writers indicated areas in which the POZ could learn from the AICs. Finally, the study explored issues of mutuality and inter-dependence, and a few guidelines are proposed for POZ.

\section{UPCSA and POZ can be more relevant in missional outlook in the African environment: A critical analysis}

There is also a deeply religious and spiritual quest which helps the reader to understand how persons nurtured in the womb of the UPCSA may at some point join an AIC. Rather than get into polemics, it is better to ask: What is it that the UPCSA has not done well, which encourages some of its members to 'vote with their feet' and join other churches? Those who have been responsible for the propagation of the Christian Gospel in Zimbabwe have not shown sufficient awareness of the need for an encounter between the Christian religion and the cosmology of the peoples outside of European cultures and traditions. It is this lack that has made Christianity either alien or superficial or both.

As the UPCSA preached in Zimbabwe, the African believer hoped for satisfaction but, to a great extent, this was in vain. The historical nature of the UPCSA and theological reflection on the 21st century missionary movements in Zimbabwe reveal that the problem started during the period of the 
propagation of Christianity. The Good News, however, is that the UPCSA can become more relevant in the African context through contextualisation. A theological reflection on the missionary movement of the 21st century in Zimbabwe reveals that the missionaries presented what amounted to a God of rules rather than a God who loves Africans. Individualism and the superiority of Western principles were considered as faith itself (Chikomo, pers. comm., 25 June 2012). It was a theology that was homogeneous and promoted abstract principles that failed to answer African spiritually. It presented a theology tied to the Western culture as the church.

In order for the UPCSA to be more relevant, it needs dialogue with African cultures. African culture is the basis on which Zimbabweans come to experience God. It is only when African culture is considered and integrated from within that they can cater for their faith. The church is improving on aspects of worship style, liturgy and the use of African instruments, but there is still more to be addressed in this regard. The UPCSA has to quench the daily religious thirst for an authentic African spirituality. This church has to offer a prophetic ministry to its members. The ministry will help the UPCSA to move away from academic to practical issues that make the gospel message a central point of life. The call for African churches to consider their impact on the church scene without any interference from the mother churches, which normally comes with funds and foreign personnel, will allow the church to become responsible in making important decisions that affect the African church and worshipper without fear or bias. Sadly Christianity in Zimbabwe came wrapped in Western culture, and the church has continued to transmit the gospel in that Western culture without the opportunity for the church to change and become more relevant and contextual with regard to African needs. The UPCSA has the potential to make African Christians children of God without abandoning their God-given culture because it is neither a sin nor an affront to their participation in the Kingdom of God.

There is great need to start afresh, to recommit and to reconcile if the church is to make a way forward. The church needs to remove some blockades through reconciling ministers and the laity (Chigwida, pers. comm., 10 October 2011). Before evangelisation starts, it is vital for the churches to learn and discern from within the context and the environment in which they operate, especially with regard to the culture in which the message is preached. Church leaders must note that each community is unique and, as such, treat it with reverence and utmost care to enlist potential membership. The church must learn to share the available space with existing religions in the area to be evangelised. It must avoid thinking for and imposing things on the inhabitants rather pursuing them. It may intensify Bible studies and allow the scriptures speak to them (communicants), with them and through them at all times.

Ministers of the word and pastors should avoid distancing themselves from the parishes lest these withdraw and the whole process collapses. They might live with their parishes and be a light to the community by, for example, moving manses into the community rather staying within the church premises as is currently the norm.

The church must attract rather than shun, condemn and judge people and be readily prepared to adapt, change and move with the time in reforming herself. It is the duty as ministers to prepare congregants to debate at all levels and to give priority to training and equipping human resources. In meetings, they should use the common language which is understood by everyone at all times.

\section{Universities and colleges}

In the institutions of learning, it is critical to start constructing African theologies that reflect on the vibrancy of cultural circumstances and that reflect the experiences of African Independent Churches in order to build the distinctiveness of black congregations (in African Churches). Universities and colleges could make psychology of religion a priority for all theological students in order to equip them to be more relevant to the community in which they minister.

\section{Conclusion}

This article advocates a new way of raising awareness in the church in Zimbabwe about the need to look at itself and the way in which it evangelises and cares for its members to avoid an exodus to the AICs. This can be done through learning from the AICs' approach to the ministry without giving up or radically altering its own nature. This is a situation where members are seeking help or advice from AICs after their normal church hours in churches founded by Western missionaries or the POZ. The spiritual poverty has caused people to shun churches founded by Western missionaries or the UPCSA for AICs.

The church in Zimbabwe needs to change in its approach to mission work and be inclusive in nature, embracing the local instruments, ideas and even ways of worship in services. This will enable members to take responsibility for shaping their lives and church within their environment. It is important for the church to create confidence and hope in it amongst the local people. This will enable them to listen and express their insights. As a result, this will bring about a radical transformation to the whole church.

\section{References}

Balcomb, A., 2014, Journey into the African sun: Soundings in search of another way of being in the world, Research Institute for Theology and Religion, UNISA, Pretoria.

Banana, S.C., 1991, Come and share: An introduction to Christian theology, Swedish Institute of Missionary Research, Uppsala.

Baur, J., 1994, 2000 years of Christianity in Africa, Paulines Publications, Nairobi.

Bax, D., 1997, The Presbyterian Church of Southern Africa: An introduction, PCSA, Johannesburg.

Bediako, K., 1999, Theology and identity: The impact of culture upon Christian thought in the second century and modern Africa, Regnum, Oxford.

Bourdillon, M.F.C., 1973, Christianity south of Zambezi, vol. 2, Mambo Press, Gwelo. Daneel, M.I., 1987, Quest for belonging, Mambo Press, Gweru. 
Henderson, G.D., 1967, The Scottish ruling elder, PCSA, Harare.

Magava, E.B., 1986, Ndebele people with their ancestral spirits but on table of the Lord with table of demons, Mambo Press, Gweru.

Mukonyora, I., 1993, Rewriting the Bible, Mambo Press, Gweru.

Nyirongo, L., 1997, The Gods of Africa or the Gods of the Bible?: The snares of African traditional religion in Biblical perspective, Potchefstroomse Universiteit, IRS, Potchefstroom.

Presbytery of Zimbabwe (POZ), 2006, Council minutes, UPCSA, Harare.

Turaki, Y., 1999, Christianity and African Gods; A method in theology, Potchefstroomse Universiteit vir CHO, Potchefstroom.

Tutu, D., 1978, 'Whither African theology?', in L.E.W. Fashole (ed.), Christianity in independent Africa, pp. 73-91, Rex Collins, London.

Uniting Presbyterian Church in Southern Africa (UPCSA), 2002, Papers for Genera Assembly, UPCSA, Johannesburg.
Uniting Presbyterian Church in Southern Africa (UPCSA), 2003, Papers for General Assembly, UPCSA, Johannesburg.

Uniting Presbyterian Church in Southern Africa (UPCSA), 2007, The manual of faith and order of the Uniting Presbyterian Church in Southern Africa, UPCSA Johannesburg.

Uniting Presbyterian Church in Southern Africa (UPCSA), 2008, Papers for Genera Assembly, UPCSA, Johannesburg.

Uniting Presbyterian Church in Southern Africa (UPCSA), 2009, Papers for General Assembly, UPCSA, Johannesburg.

Uniting Presbyterian Church in Southern Africa (UPCSA), 2010, Papers for General Assembly, UPCSA, Johannesburg.

Uniting Presbyterian Church in Southern Africa (UPCSA), 2012, Papers for General Assembly, UPCSA, Johannesburg.

Weller, J., 1984, Mainstream Christianity, Mambo Press, Gweru.

Zvobgo, C.J., 1996, A history of Christian mission in Zimbabwe, Mambo Press, Gwelo. 